\title{
KECERNAAN BAHAN KERING, RETENSI NITROGEN DAN ENERGI METABOLIS RANSUM AYAM PEDAGING YANG MENGGUNAKAN TEPUNG LIMBAH LABU KUNING (Cucurbita moschata)
}

\author{
Ryan Hendrik Herryanto, Jet S. Mandey*, Ivonne M. Untu, Cathrien. A. Rahasia
}

Fakultas Peternakan Universitas Sam Ratulangi Manado, 95115

\begin{abstract}
ABSTRAK
Penelitian ini bertujuan untuk mengetahui kecernaan bahan kering (KcBK), retensi nitrogen $(\mathrm{RN})$ dan energi metabolis semu terkoreksi nitrogen (AMEn) ransum ayam pedaging yang menggunakan tepung limbah labu kuning (Cucurbita moschata). Penelitian dilakukan dengan menggunakan 20 ekor ayam pedaging unsexed, strain CP 707 berumur 5 minggu, dengan rataan berat badan \pm 1073 gram. Rancangan yang digunakan adalah rancangan acak lengkap (RAL) yang terdiri dari 4 perlakuan 5 ulangan. Uji lanjut yang digunakan adalah Beda Nyata Jujur (BNJ). Perlakuan yang digunakan adalah: $\mathrm{R}_{0}=100 \%$ ransum basal $(\mathrm{RB})+0 \%$ tepung limbah labu kuning (TLLK), $\mathrm{R}_{1}=95 \% \mathrm{RB}+5 \%$ TLLK, $\mathrm{R}_{2}=90 \% \mathrm{RB}+10 \%$ TLLK, $\mathrm{R}_{3}=85 \% \mathrm{RB}+$ $15 \%$ TLLK. Hasil analisis keragaman menunjukkan bahwa perlakuan berpengaruh nyata $(\mathrm{P}<0,05)$ terhadap nilai retensi nitrogen $(\mathrm{RN})$ dan tidak berpengaruh nyata $(\mathrm{P}>0,05)$ terhadap nilai kecernaan bahan kering (KcBK) dan nilai energi metabolis semu terkoreksi nitrogen (AMEn). Hasil uji lanjut BNJ terhadap nilai $\mathrm{RN}$ menunjukkan bahwa perlakuan $\mathrm{R} 0$ (82.08\%), R1 (79.05\%) dan R2 (77.76\%) berbeda nyata lebih tinggi dibandingkan dengan perlakuan R3 (72.31), tetapi antara R0, R1 dan R2 tidak berbeda. Berdasarkan hasil penelitian ini dapat disimpulkan bahwa tepung limbah kuning (Cucurbita moschata) dapat digunakan sebagai salah satu pakan alternatif dalam ransum ayam pedaging sampai $15 \%$ dilihat dari kecernaan bahan kering, retensi nitrogen dan energi metabolis.
\end{abstract}

*Kosepondensi (corresponding author)

Email : jetsm_fapet@yahoo.co.id
Kata Kunci : Ayam pedaging, Kecernaan bahan kering, Energi metabolis Retensi nitrogen, Limbah labu kuning.

\section{ABSTRACT}

\section{DIGESTIBILITY OF DRY} MATTER, NITROGEN RETENTION AND METABOLIC ENERGY IN RATION OF BROILERS USING YELLOW PUMPKIN MEAL (Cucurbita moschata). Research was conducted to evaluate digestibility of dry matter, nitrogen retention and metabolic energy corrected to nitrogen in ration of broilers using yellow pumpkin meal (Cucurbita moschata). The total of 20 unsexed broilers of CP 707 strain at age of 5 weeks old with the average body weight of 1073 grams were used in this study. The completely randomized design involving 4 treatments and 5 replications in each treatment was applied at the experimental unit. The significant treatments were tested using honestly significant difference test. The treatments were including $100 \%$ basal ration without yellow pumpkin meal (R0), 95\% basal ration added with $5 \%$ yellow pumpkin meal (R1), $90 \%$ basal ration added with $10 \%$ yellow pumpkin meal (R2), and $85 \%$ basal ration added with $15 \%$ yellow pumpkin meal (R3). Results of analysis of variance showed that treatments significantly affected $(\mathrm{P}<0,05)$ nitrogen retention value, but did not significantly affected $(\mathrm{P}>0,05)$ dry matter digestibility and metabolic energy corrected to nitrogen in ration. Based on honestly significant difference test, treatments of R0, R1 and R2 were higher compared with R3. Among treatments of R0, R1 and R2 were not significantly different. Therefore, it can be concluded that yellow pumpkin meal (Cucurbita moschata) was potential to be the alternative material ingredient up to 15 percents in ration of broilers based on digestibility of dry 
matter, nitrogen retention and metabolic energy.

Key Words: Broiler, Dry matter, Metabolic energy, Nitrogen retention, Yellow pumpkin meal.

\section{PENDAHULUAN}

Daging ayam pedaging merupakan salah satu sumber protein hewani yang murah dibanding dengan daging yang lain. Keunggulan memelihara ayam pedaging adalah pertumbuhannya sangat cepat, sehingga dapat dipanen pada umur 5 minggu, dengan bobot rata-rata $1,5 \mathrm{~kg}$. Ayam pedaging sangat efisien dalam mengubah pakan menjadi daging. Pakan merupakan faktor yang sangat berpengaruh dalam menentukan keberhasilan pemeliharaan ayam, khususnya ayam pedaging. Biaya pakan mencapai $60-70 \%$ dari total biaya produksi.

Pakan yang dijual di pasaran saat ini masih mengandalkan bahan baku impor yang ketersediaannya terbatas dan harganya relatif mahal karena mengikuti harga pasar dunia yang selalu berfluktuasi. Hal ini dapat diatasi dengan mencari pakan alternatif/pakan lokal yang belum lazim digunakan dan banyak dijumpai di Indonesia terlebih khusus di kota Manado, salah satunya adalah limbah labu kuning (Cucurbita moschata).
Limbah merupakan sampah yang memberi dampak pada manusia dan lingkungan. Limbah labu kuning merupakan limbah yang banyak ditemui di sekitar restoran makanan khas kota Manado dan di sekitar tempat penjualan kebutuhan pangan (pasar). Labu kuning merupakan tanaman atau buah yang sudah sangat populer di masyarakat Indonesia. Labu kuning di Sulawesi Utara lebih dikenal dengan istilah sambiki. Daging labu merupakan bahan utama di samping beras dan jagung dalam pembuatan bubur manado.

Ketersediaan limbah labu kuning terus meningkat sejalan dengan meningkatnya konsumsi masyarakat terhadap hasil olahan berbagai jenis makanan dari daging buah labu. Tingkat produksi buah labu kuning di Indonesia relatif tinggi, dan produksinya dari tahun ke tahun terus meningkat. Pada tahun 2003 dari 103.451 ton meningkat menjadi 212.697 ton dan pada tahun 2006 sampai dengan tahun 2010 menjadi 369.846 ton (Santoso et al., 2013).

Komposisi zat nutrien limbah labu kuning per $100 \mathrm{~g}$ adalah protein $23.14 \%$, lemak $14.59 \%$, serat kasar $17.48 \%$, kalsium $0,76 \%$, fosfor $0,75 \%$ dan energi bruto 3882,4 kkal (Komalig et al., 2016). Kandungan protein dan energi pada limbah labu kuning cukup tinggi, namun dalam pemanfaatannya perlu dipertimbangkan 
mengenai protein tercerna dan energi metabolis limbah labu kuning dalam ransum karena belum adanya hasil riset yang tersedia.

Retensi nitrogen dan energi metabolis merupakan salah satu metode untuk menilai kualitas protein dan kualitas energi ransum pada ternak (Scott et al., 1982). Hal tersebut dapat dilakukan dengan mengukur konsumsi nitrogen dan energi dikurangi pengeluaran nitrogen dan energi dalam feces dan urine, sehingga diketahui jumlah nitrogen dan energi yang tertinggal dalam tubuh.

\section{MATERI DAN METODE PENELITIAN}

Penelitian ini dilaksanakan di Kandang Unggas, Fakultas Peternakan, Universitas Sam Ratulangi Manado. Penelitian ini menggunakan 20 ekor ayam pedaging unsexed, strain CP 707 berumur 5 minggu dengan rataan berat badan \pm 1073 gram.

Kandang yang digunakan dalam penelitian ini adalah kandang individu berukuran 20 × 30 × $30 \mathrm{~cm}$ sebanyak 20 unit yang dilengkapi dengan tempat makan dan minum. Perlengkapan lain yang digunakan adalah timbangan "Digital Ohaus" (untuk menimbang ayam, ransum dan ekskreta), wadah penampang ekskreta, tabung penyemprot, alumunium foil, pengaduk dan oven untuk mengeringkan ekskreta. Bahan kimia yang digunakan selama percobaan ini yaitu asam sulfat 5\%, yang berfungsi untuk mencegah hilangnya $\mathrm{N}$ pada ekskreta.

Pakan yang digunakan terdiri dari jagung kuning, tepung ikan, tepung kedelai, dedak halus, bungkil kelapa, minyak, top mix dan limbah labu kuning, dengan prosedur pembuatannya disajikan pada Gambar 1.

\section{Limbah labu kuning segar}

Dibersihkan (dipisahkan dari limbah lain)

Dipotong ukuran kecil

Dipisahkan antara kulit dan bagian tengah (serat berlendir dan biji)

Dikeringkan melalui sinar matahari selama $\pm 3-4$ hari

\section{Digiling}

Tepung limbah labu kuning

Gambar 1. Skema Pembuatan Tepung Limbah Labu Kuning.

Limbah labu kuning yang digunakan diperoleh dari tempat penjualan bahan pangan (pasar) Bersehati Manado. Komposisi zat nutrien dan energi bruto ransum basal dan tepung limbah labu kuning pada Tabel 1, dan komposisi zat nutrien dan energi bruto ransum perlakuan pada Tabel 2. Penelitian ini merupakan penelitian eksperimental dengan menggunakan Rancangan Acak Lengkap (Steel and Torrie, 1995) yang terdiri dari 4 
perlakuan dan 5 ulangan, dengan susunan sebagai berikut :

$\mathrm{R}_{0}=$ Ransum Basal 100\% (Tanpa Tepung Limbah Labu Kuning).

$\mathrm{R}_{1}=$ Ransum Basal 95\% + Tepung Limbah Labu Kuning 5\%.

$\mathrm{R}_{2}=$ Ransum Basal 90\% + Tepung Limbah Labu Kuning $10 \%$.

$\mathrm{R}_{3}=$ Ransum Basal 85\% + Tepung Limbah Labu Kuning $15 \%$.

Uji lanjut dilakukan untuk perlakuan yang berbeda nyata dengan uji Beda Nyata Jujur (BNJ). Penempatan ternak dan perlakuan ke setiap unit kandang dilakukan secara acak.

Variabel yang diukur yaitu kecernaan bahan kering, retensi nitrogen dan energi metabolis terkoreksi nitrogen menurut petunjuk Zarei (2006) dengan menggunakan rumus:

\section{Kecernaan Bahan Kering (KcBK)}

$$
\begin{aligned}
& \operatorname{KcBK}(\%)= \\
& \frac{\text { Konsumsi BK }(\mathrm{g})-\mathrm{BK} \text { eks kreta }(\mathrm{g})}{\text { Konsumsi BK }(\mathrm{g})} \times 100 \%
\end{aligned}
$$

Keterangan :

$\begin{array}{ll}\text { KcBK } & \text { : Kecernaan Bahan Kering } \\ \text { Konsumsi BK }: \text { Konsumsi Bahan Kering } & \\ & (\mathrm{g}) \\ \text { BK ekskreta } & \begin{array}{l}\text { : Bahan Kering dalam } \\ \text { ekskreta }(\mathrm{g})\end{array}\end{array}$

\section{Retensi Nitrogen (RN)}

$\mathrm{RN}(\%)=\frac{(\mathrm{Fi} \times \mathrm{Nf})-(\mathrm{E} \times \mathrm{Ne})}{(\mathrm{Fi} \times \mathrm{Nf})} \times 100 \%$

Keterangan:

$\mathrm{RN}$ : Retensi Nitrogen (\%)

$\mathrm{N} f \quad$ : Nitrogen Pakan (\%)

$\mathrm{Ne} \quad$ : Nitrogen Ekskreta(\%)

$\mathrm{Fi} \quad$ : Pakan yang dikonsumsi (g)

E : Jumlah Ekskreta (g)

\section{Energi Metabolis}

$$
A M E n=\frac{(F i \times \text { GEf })-(E \times \text { GEe })-(\text { NR } \times \text { K })}{F i}
$$

Keterangan:

AMEn: Energi metabolis semu yang dikoreksi dengan retensi nitrogen (Kkal/kg)

Fi: Banyaknya pakan yang dikonsumsi (g)

E: Jumlah Ekskreta (g)

GEf: $\quad$ Energi Bruto pakan (Kkal/kg)

$\mathrm{GE} e$ : Energi Bruto ekskreta (Kkal/kg)

$\mathrm{RN}$ : $\quad$ Retensi Nitrogen $(\mathrm{g}) \mathrm{NR}=(\mathrm{F} i \mathrm{x}$ $\mathrm{N} f)-(\mathrm{E} \times \mathrm{N} e)$

K: $\quad$ Konstanta koreksi untuk nilai energi nitrogen yang diretensi (8.73 Kkal/kg untuk setiap gram nitrogen. 
Tabel 1. Komposisi Zat Nutrien dan Energi Bruto Ransum Basal dan Tepung Limbah Labu Kuning.

\begin{tabular}{lcc}
\hline Zat Nutrien & Pakan Basal* & TLLK** \\
\hline Abu (\%) & 6,15 & 6,53 \\
Protein (\%) & 21,50 & 23,14 \\
Serat Kasar (\%) & 4,64 & 17,48 \\
Lemak (\%) & 12,94 & 14,59 \\
Beta-N & 54,77 & 38,26 \\
Energi Bruto (Kcal) & 3901,25 & 3882,40 \\
\hline Keterangan & $:-$ TLLK = Tepung Limbah Labu Kuning & \\
& $*$ Hasil Analisis Laboratorium Nutrisi Ternak Ruminansia dan Kimia Makanan Ternak \\
& Fakultas Peternakan, UNPAD, Bandung (2018).
\end{tabular}

Tabel 2. Komposisi Zat Nutrien dan Energi Bruto Ransum Perlakuan

\begin{tabular}{lcccc}
\hline Perlakuan & R0 & R1 & R2 & R3 \\
\hline Pakan Basal & 100 & 95 & 90 & 85 \\
Limbah Labu Kuning & 0 & 5 & 10 & 15 \\
\hline Zat Nutrien dan Energi Bruto & & & & \\
\hline Abu (\%) & 6,15 & 6,17 & 6,19 & 6,21 \\
Protein (\%) & 21,50 & 21,58 & 21,66 & 21,75 \\
Serat Kasar (\%) & 4,64 & 5,28 & 5,92 & 6,57 \\
Lemak (\%) & 12,94 & 13,02 & 13,11 & 13,19 \\
Beta-N & 54,77 & 53,94 & 53,12 & 52,29 \\
Energi Bruto (Kcal) & 3901,25 & 3900,31 & 3899,37 & 3898,42 \\
\hline
\end{tabular}

Keterangan : Dihitung berdasarkan Tabel 1.

\section{HASIL DAN PEMBAHASAN}

Rataan nilai kecernaan bahan kering $(\mathrm{KcBK})$, nilai retensi nitrogen $(\mathrm{RN})$ dan nilai energi metabolis terkoreksi nitrogen (AMEn) ransum ayam pedaging yang menggunakan tepung limbah labu kuning disajikan pada Tabel 3.

\section{Pengaruh Perlakuan Terhadap Nilai Kecernaan Bahan Kering}

Nilai kecernaan bahan kering $(\mathrm{KcBK})$ diperoleh dari selisih antara 
Tabel 3. Rataan Nilai Kecernaan Bahan Kering, Retensi Nitrogen dan Energi Metabolis Terkoreksi Nitrogen Ransum Ayam Pedaging yang Menggunakan Tepung Limbah Labu Kuning.

\begin{tabular}{lllll}
\hline \multirow{2}{*}{ Parameter } & \multicolumn{5}{c}{ Perlakuan } \\
\cline { 2 - 5 } & R0 & R1 & R2 & R3 \\
\hline KcBK (\%) & 67,71 & 68,22 & 70,26 & 66,52 \\
RN (\%) & $82,08^{\mathrm{a}}$ & $79,05^{\mathrm{a}}$ & $77,76^{\mathrm{a}}$ & $72,31^{\mathrm{b}}$ \\
AMEn (Kcal) & 3053,60 & 3095,46 & 3152,11 & 3058,15 \\
\hline
\end{tabular}

Keterangan: Superskrip yang berbeda pada baris yang sama menunjukkan perbedaan yang nyata $(\mathrm{P}<0,05) . \mathrm{KcBK}=$ Kecernaan Bahan Kering; $\mathrm{RN}=$ Retensi Nitrogen; AMEn $=$ Energi Metabolis Terkoreksi Nitrogen.

jumlah bahan kering yang dikonsumsi ayam pedaging dikurangi dengan jumlah bahan kering dalam ekskreta.

Rataan nilai KcBK ransum ayam pedaging yang menggunakan tepung limbah labu kuning dalam penelitian ini berkisar antara 66,52\% - 70,26\%. Nilai KcBK ini masih berada pada kisaran yang rekomendasi Blair et al. (1990) yang disitasi oleh Rembet et al. (2016) bahwa ransum ayam pedaging fase finisher, kecernaan bahan keringnya berkisar pada nilai $50-80 \%$. Nilai $\mathrm{KcBK}$ berturut-turut dari yang tertinggi diperoleh pada perlakuan R2 (70,26\%) selanjutnya diikuti oleh R1 (68,22\%), R0 (67,71\%) dan R3 $(66,52 \%)$.

Hasil analisis keragaman menunjukkan bahwa penggunaan tepung limbah labu kuning tidak berpengaruh nyata $(\mathrm{P}>0,05)$ terhadap nilai $\mathrm{KcBK}$. Hal ini membuktikan bahwa penggunaan tepung limbah labu kuning sampai $15 \%$ tidak menimbulkan efek negatif terhadap nilai KcBK. Tinggi rendahnya kandungan bahan kering yang dicerna berhubungan dengan banyaknya kandungan nutrien yang terserap. Tillman et al. (1998) mengemukakan bahwa bahan kering yang diekskresikan dalam ekskreta merupakan zat-zat nutrien yang tidak diserap tubuh. Berdasarkan hasil penelitian ini dapat direkomendasikan bahwa dengan penggunaan tepung limbah labu kuning sampai tingkat $15 \%$ memberikan pengaruh yang sama baiknya dengan ransum kontrol atau tanpa tepung limbah labu kuning (R0) terhadap nilai kecernaan bahan kering ayam pedaging.

\section{Pengaruh Perlakuan Terhadap Nilai Retensi Nitrogen}

$$
\text { Nilai retensi nitrogen (RN) }
$$
diperoleh dari selisih antara jumlah nitrogen yang dikonsumsi dikurangi dengan jumlah nitrogen dalam ekskreta. 
Hasil analisis keragaman menunjukkan bahwa penggunaan tepung limbah labu kuning berpengaruh nyata $(\mathrm{P}<0,05)$ terhadap nilai RN. Hasil uji lanjut BNJ menunjukkan perlakuan R0, R1 dan R2 berbeda nyata lebih tinggi dibandingkan dengan perlakuan R3, tetapi antara R0, R1 dan R2 tidak berbeda.

Rataan RN pada penelitian ini berkisar antara 72,31\% - 82,08\%, nilai $\mathrm{RN}$ ini berada diatas efisiensi protein yang diretensi oleh ayam pedaging menurut Wahju (2004) adalah 67\%. Dijelaskan lebih lanjut bahwa yang diretensi untuk pertumbuhan jaringan per hari, penggantian bulu dan penggantian nitrogen endogen yang hilang. Peningkatan nilai RN tersebut dipengaruhi oleh meningkatnya kecernaan nitrogen. Nitrogen yang diretensi tersebut meningkat disebabkan oleh proses pencernaan dan absorbsi zat-zat nutrien yang lebih baik sehingga memperlambat rate of passage nutrien dalam saluran pencernaan (Mateos et al., 1982).

Nilai RN tertinggi pada hasil penelitian ini terdapat pada perlakuan R0 dengan kandungan protein ransum 21,50\%, dan menurun pada perlakuan R1, R2 dan R3 dengan kandungan protein ransum berturut-turut $21,58 \%, \quad 21,66 \%$ dan 21,75\%. Menurut Ewing (1963) yang disitasi oleh The et al. (2017) menyatakan bahwa meningkatnya protein dalam ransum dapat menurunkan $\mathrm{RN}$ dikarenakan sebagian protein digunakan untuk memenuhi kebutuhan energi. Retensi nitrogen juga dipengaruhi oleh jumlah serat kasar yang dikonsumsi. Kebutuhan serat kasar untuk ayam pedaging maksimal $6 \%$ (Badan Stadardisasi Nasional, 2006).

Suciani et al. (2011) menyatakan bahwa ayam pedaging tidak dapat mencerna serat kasar yang terlalu tinggi karena akan menyebabkan efisiensi penggunaan zat-zat nutrien mengalami penurunan. Serat kasar dalam penelitian ini cukup mempengaruhi nilai nitrogen yang diretensi sehingga menurunkan RN namun tetap menunjukkan respon yang positif. Retensi Nitrogen bernilai positif artinya bahwa tubuh ayam pedaging mampu menyerap nitrogen, sehingga ayam pedaging tersebut mendapatkan pertambahan bobot badan karena tenunan ototnya bertambah. Hasil penelitian ini sejalan dengan yang dilaporkan Dady et al. (2016) bahwa dengan kandungan protein yang sama (20\%) pada setiap perlakuan, pemberian 6\% daun murbei (Morus alba) dalam ransum ayam pedaging nyata menurunkan nilai retensi nitrogen dibanding ransum kontrol. Retensi nitrogen juga dipengaruhi oleh beberapa faktor lain yaitu, konsumsi ransum, konsumsi protein, kualitas protein, daya cerna protein, serat kasar, imbangan zat-zat nutrien dalam ransum dan kondisi ternak. 
Penelitian ini membuktikan bahwa sampai tingkat $15 \%$ menunjukkan respon positif pada ayam pedaging terhadap nilai nitrogen yang diretensi. Retensi Nitrogen akan negatif apabila nilai nitrogen yang diekskresikan lebih tinggi dari nilai nitrogen yang diretensi, sebaliknya $\mathrm{RN}$ akan positif apabila nilai nitrogen yang diretensi lebih tinggi dari nilai nitrogen yang diekskresikan melalui ekskreta.

\section{Pengaruh Perlakuan Terhadap Nilai Energi Metabolis}

Nilai energi metabolis dalam penelitian ini merupakan nilai energi metabolis semu terkoreksi nitrogen (AMEn).

Rataan nilai energi metabolis ayam pedaging yang menggunakan tepung limbah labu kuning dalam penelitian ini berkisar antara 3053,60 Kcal - 3152,11 Kcal. Nilai AMEn berturut-turut dari yang tertinggi diperoleh pada perlakuan R2 $(3152,11$ Kcal) selanjutnya R1 (3095,46 Kcal), R3 (3058,15 Kcal), dan R0 (3053,60 Kcal).

Hasil analisis keragaman menunjukkan bahwa penggunaan tepung limbah labu kuning tidak berpengaruh nyata $(\mathrm{P}>0.05)$ terhadap nilai AMEn. Hal ini membuktikan bahwa penggunaan tepung limbah labu kuning memberikan hasil yang sama (tidak berbeda) antar perlakuan terhadap besaran energi yang dimetabolis.

Keseragaman nilai energi metabolis yang dihasilkan membuktikan tidak adanya efek negatif yang ditimbulkan terhadap nilai energi yang dimetabolis dengan pemberian tepung limbah labu kuning sampai $15 \%$ dalam ransum. Nilai AMEn pada penelitian ini $(3053,60 \mathrm{Kcal}-3152,11$ Kcal) lebih tinggi dibandingkan dengan yang dilaporkan The et al. (2017) dimana nilai AMEn yang dihasilkan dengan penggunaan tepung limbah sawi putih (Brassica rapa L. subsp. pekinesis) yaitu 2117,00 Kcal - 3141,57 Kcal dan Siabandi et al. (2018) dengan penggunaan tepung silase kulit pisang kapok (Musa paradisiaca formatypica) dengan nilai AMEn yaitu 2557,31 Kcal - 3040,05 Kcal. Kandungan zat nutrien dalam ransum pada imbangan yang tepat dan kandungan zat nutrien dalam ransum perlakuan mempunyai daya cerna yang tinggi. Sejalan dengan pendapat Williams et al. (1990), bahwa faktor yang mempengaruhi energi metabolis adalah daya cerna dan daya cerna yang rendah menyebabkan banyak energi yang hilang melalui ekskreta. Dapat direkomendasikan bahwa dengan menggunakan tepung limbah labu kuning sebagai pengganti sebagian ransum sampai tingkat $15 \%$ memberikan pengaruh yang sama baiknya dengan ransum kontrol atau tanpa tepung limbah labu kuning (R0) 
terhadap nilai energi metabolis ayam pedaging. Berbeda tidak nyata $(\mathrm{P}>0.05)$ antar perlakuan terhadap nilai KcBK dan AMEn serta nilai RN bersifat positif dalam penelitian ini mengindikasikan bahwa tepung limbah labu kuning (Cucurbita moschata) dapat menggantikan $15 \%$ ransum ayam pedaging.

Hasil penelitian ini telah menjelaskan bahwa tujuan penelitian ini tercapai karena dapat memanfaatkan tepung limbah labu kuning (Cucurbita moschata) yang dianggap sebagai limbah pertanian dapat menjadi bahan pakan alternatif dalam ransum ayam pedaging. Hasil penelitian ini merupakan suatu langkah maju dalam menemukan bahanbahan pakan non konvensional untuk menggantikan bahan-bahan pakan konvensional dalam ransum ayam pedaging.

\section{KESIMPULAN}

Berdasarkan hasil penelitian ini dapat disimpulkan bahwa tepung limbah labu kuning (Cucurbita moschata) dapat digunakan sebagai salah satu pakan alternatif dalam ransum ayam pedaging sampai $15 \%$ dilihat dari nilai kecernaan bahan kering, retensi nitrogen dan energi metabolis.

\section{DAFTAR PUSTAKA}

Badan Stadardisasi Nasional. 2006. Pakan Ayam Ras Pedaging (Broiler Starter dan Finisher). SNI 01-3930-2006.

Dady, Z., J. S. Mandey, M. R. Imbar, dan M. N. Regar. 2016. Nilai retensi nitrogen dan energi metabolis ransum menggunakan daun murbei (Morus alba) segar pada broiler. Jurnal Zootek 36(1) : 42-50.

Komalig, D. F., J. R. Leke, J. Laihat, dan C. Sarajar. 2016. Penggunaan tepung limbah labu kuning dalam ransum terhadap penampilan produksi ayam ras petelur. Jurnal Zootek 36(2) : 342-352.

Mateos, G. G., J. L. Sell, dan J. A. Eastwood. 1982. Rate of food passage (transit time) as influence by level supplemental fat. J. of Poult. Sci. 61: 94-100.

Rembet, V., J. F. Umboh, Y. L. R Tulung dan Y. H. S Kowel. 2016. Kecernaan protein dan energi ransum broiler yang menggunakan tepung Maggot (Hermetia illucens) sebagai pengganti tepung ikan. Jurnal Zootek 36(1): 13-22.

Santoso, E. B., Basito, dan D. Rahadian. 2013. Pengaruh penambahan berbagai jenis dan kosentrasi susu terhadap sifat sensoris dan sifat fisikokimia puree labu kuning (Cucurbita moschata). Jurnal Teknosains Pangan 2(3): 16-24.

Scott, M. L., C. Neisheim dan R. J. Young. 1982. Nutrition of Chiken $3^{\text {rd }}$ Edition. Published M, L Scoot and Assosciated: Ithaca. New York. 
Siabandi, R., B. Bagau, M. R. Imbar dan M. N. Regar. 2018. Retensi nitrogen dan energi metabolis ransum broiler yang mengandung tepung silase kulit pisang kepok (Musa paradisiaca formatypicai). Jurnal Zootek 38 (1): 226-234.

Suciani, K., W. Parimartha, N. L. G. Sumardani, I. G. N. G. Bidura, I. G. N. Kayana dan S. A. Lindawati. 2011. Penambahan multi enzim dan ragi tape dalam ransum berserat tinggi (pod kakao) untuk menurunkan kolestrol daging ayam broiler. Jurnal Veteriner 12 (1):6976.

Steel, R. G. D dan J. H. Torrie. 1995. Prinsip dan Prosedur Statistika : Suatu Pendekatan Biometrik. Terjemahan B. Sumantri. Gramedia Pustaka Utama, Jakarta.

The, F., J. S. Mandey, Y. H. S. Kowel dan M. N. Regar. 2017. Nilai retensi nitrogen dan energi metabolis broiler yang diberi ransum tepung limbah sawi putih (Brassica rapa L. subsp. pekinesis). Jurnal Zootek 37(1) :4149.
Tillman, A. D., H. Hartadi. S. Reksohadiprodjo, S. P. Kusumo dan S. Lebdosoekojo. 1998. Ilmu Makanan Ternak Dasar.

Wahju, J. 2004. Ilmu Nutrisi Unggas. Edisi ke-4. Gadjah Mada University Press, Yogyakarta.

Williams, C. M., C. G. Lee, J. D. Garlich and C. H. S. Jason. 1990. Evalution of a bacterial feather fermentation product, feather- lysate, as a feed protein. J. Sci. 70: 85-95.

Zarei, A. 2006. Apparent and true metabolizable energy in Artemia meal. Int. J. of Poult. Sci. 5 (7): 627628. 